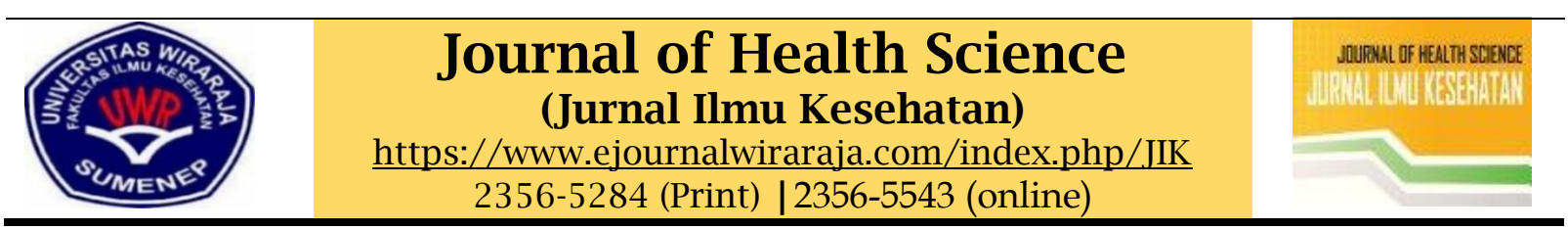

\title{
Literatur Review : Terapy Musik Terhadap Hipertensi Kehamilan
}

\author{
Ahmaniyah ${ }^{1}$, Ratna Indriyani ${ }^{2}$ \\ 1,2Program Studi S1 Kbidanan, Universitas Wiararaja, Madura, Indonesia \\ 1ahmaniyah.fik@wiraraja.ac.id *; ratnaindriyani@wiraraja.ac.id \\ *Corresponding Author
}

\begin{tabular}{l}
\hline Informasi artikel \\
\hline Received: $17-04-2020$ \\
Revised: 22-05-2020 \\
Accepted: 31-05-2020
\end{tabular}

\section{Kata kunci:}

Hamil

Musik

Hipertensi

\begin{abstract}
ABSTRAK
Hipertensi dalam kehamilan merupakan komplikasi kehamilan secara umum, yang mempengaruhi $2 \%$ wanita hamil di dunia. merupakan penyebab kematian ibu hamil di dunia, penanganan hipertensi dilakukan dengan konvensional yaitu obat penurun hipertensi, tetapi pengobatan yang konvensinal ini banyak kendalanya karena berkaitan dengan ibu hamil yang pasti pasti akan berkaitan dengan janin yang kandungnya. Tujuan : menganalisis terapi musik dalam menurunkan tekanan darah pada ibu hamil. Metode : Penelitian ini ditinjau dari basis data elektronik termasuk Science Direct, Pubmed, Google Cendekia. Dengan kata kunci “ hipertensi, music, kehamilan”. Sebanyak 4 dari 5.840 rentang publikasi dari 2015 hingga Desember 2019, yang membahas tentang terapi musik pada ibu hamil yang menagalami hipertensi dan disajikan dalam bahasa Inggris, dimasukkan dalam ulasan ini. Selain itu, bab buku teks dan pedoman yang relevan diperiksa untuk menangkap informasi lebih lanjut atau laporan tambahan yang tidak diidentifikasi dalam pencarian elektronik. Hasil : dari analisis banyak penelitian menunjukkan bahwa terapi musik dengan rata - rata durasi 30 menit selama 1 bulan menunjukkan hasil yang signifikan terhadap penurunan hipertensi pada ibu hamil Kesimpulan : Terapi musik adalah usaha yang signifikan dikombinasi dengan terapi konvensional untuk penurunan tekanan sistolik dan diastolik pada ibu hamil yang hipertensi.

\section{ABSTRACT}

Hypertension in pregnancy is a complication of pregnancy in general, which affects $2 \%$ of pregnant women in the world. is a cause of death of pregnant women in the world, the handling of hypertension is done conventionally, namely hypertension-lowering drugs, but this conventional treatment has many obstacles because it is related to pregnant women who will certainly be related to the fetus. Objective: to analyze music therapy in reducing blood pressure in pregnant women. Methods: This research was reviewed from electronic databases including Science Direct, Pubmed, Google Scholar. With the keywords "hypertension, music, pregnancy". A total of 4 of the 5,840 publication ranges from 2015 to December 2019, which discussed music therapy in pregnant women with hypertension and were presented in English, were included in this review. In addition, relevant textbook chapters and guidelines are examined to capture further information or additional reports not identified in the electronic search. Results: analysis of many studies showed that music therapy with an average duration of 30 minutes for 1 month showed significant results in reducing hypertension in pregnant women. Conclusion: Music therapy is a significant effort combined with conventional therapy for reducing systolic and diastolic pressure in hypertensive pregnant women.
\end{abstract}

Key word:

Pregnancy

Music

Hypertension

\section{Pendahuluan}

Hipertensi adalah penyebab kematian ibu hamil didunia, yang menyebabkan komplikasi kehamilan secara umum, dan mempengaruhi $2 \%$ wanita hamil di dunia..(Pennings et al., 2011) fakor penyebab terjadinya hipertensi dalam kehamilan tidak diketahui secara pasti, tetapi dari hasil penelitian faktor keturunan dan kekebalan tubuh, serta 
fungsi plasenta dan reaksi inflamasi yang abnormal merupakan penyebab dari terjadiya hipertensi dalam kehamilan. (Ayuk \& Matijevic, 2006; Deveer et al., 2013) Hipertensi dalam kehamilan memiliki dampak yang serius pada kehamilan, seperti Kematian bayi perinatal, asphyxia neonatorum, gawat janin, solusio plasenta, perdarahan pasca persalinan. (Kintiraki, Papakatsika, Kotronis, Goulis, \& Kotsis, 2015) penanganan hipertensi dilakukan dengan konvensional yaitu obat penurun hipertensi, tetapi pengobatan yangkonvensinal ini banyak kendalanya karena berkaitan dengan ibu hamil yang pasti akan berkaitan dengan janin yang kandungnya, jadi diperlukan terapi komplementer yaitu dengan Terapi musik, yang merupakan usaha meningkatkan kualitas fisik dan mental dengan rangsangan suara yang terdiri dari melodi, ritme, harmoni, timbre, bentuk dan gaya yang diorganisir sedemikian rupa hingga tercipta musik yang bermanfaat untuk kesehatan fisik dan mental.

Penggabungan terapi musik dan obat-obatan konvensional tidak hanya memberikan hasil anti-hipertensi, tetapi juga menurunkan detak jantung saat istirahat dan aktivitas saraf simpatik. Penerapan terapi musik pada pasien hipertensi yang telah menjalani operasi caesar juga dapat menurunkan kadar angiotensin II.(Geretsegger et al., 2015) Musik memiliki kekuatan untuk mengobati penyakit dan meningkatkan kemampuan pikiran seseorang. Ketika musik diterapkan menjadi sebuah terapi, musik dapat meningkatkan, memulihkan, dan memelihara kesehatan fisik, mental, emosional, sosial dan spiritual. Hal ini disebabkan musik memiliki beberapa kelebihan, yaitu karena musik bersifat nyaman, menenangkan, membuat rileks, berstruktur, dan universal. Perlu diingat bahwa banyak dari proses dalam hidup kita selalu ber-irama. Sebagai contoh, nafas kita, detak jantung, dan pulsasi semuanya berulang dan berirama.

Terapi musik merupakan terapi yang universal dan bisa diterima oleh semua orang karena kita tidak membutuhkan kerja otak yang berat untuk menginterpretasi alunan musik. Terapi musik sangat mudah diterima organ pendengaran kita dan kemudian melalui saraf pendengaran disalurkan ke bagian otak yang memproses emosi (sistem limbik). Terapi musik telah terbukti efektif dalam memanipulasi reaksi stres, kecemasan, rasa sakit, dan ketegangan otot.(Liao, Jiang, \& Wang, 2015). Tujuan dari penelitian ini menganalisis terapi musik yang palingefektif dalam menurunkan tekanan darah pada ibu hamil yang mengalami hipertensi.

\section{Metode}

Penelitian ini ditinjau dari basis data elektronik termasuk Science Direct, Pubmed, Google Cendekia dan situs web terkait lainnya. Dengan kata kunci “ hipertensi, music, kehamilan". Sebanyak 4 dari 5.840 yang kemudian dipilih sesuai dengan tema dan dicari persamaannya dari setiap jurnal yang ditemukan. rentang publikasi dari 2015 hingga Desember 2019, yang membahas tentang terapi musik pada ibu hamil yang menagalami hipertensi dan disajikan dalam bahasa Inggris, dimasukkan dalam ulasan ini. Selain itu, bab buku teks dan pedoman yang relevan diperiksa untuk menangkap informasi lebih lanjut atau laporan tambahan yang tidak diidentifikasi dalam pencarian elektronik.

\section{Hasil dan pembahasan}

Tabel 1. Karakterisik yang termasuk dalam penelitian

\begin{tabular}{llll}
\hline \multicolumn{1}{c}{ Peneliti } & \multicolumn{1}{c}{ Sampel } & \multicolumn{1}{c}{ Prosedur } & Hasil \\
\hline 1.(Cao et al., & 60 ibu hamil & Pasien pada kedua kelompok diberi Hasilnya menunjukkan bahwa \\
2016) (2018) & hipetensi & terapeutik konvensional, termasuk terapi musik merupakan \\
& dengan usia & spasmolisis dengan magnesium suplemen yang efektif dalam \\
& kehamilan 20 & sulfat, menurunkan tekanan darah menurunkan tekanan darah \\
& minggu & dengan nifedipin dan lainnya. Pasien pada ibu hamil yang \\
& & dalam kelompok observasi juga hipertensi, mengurangi serum \\
& & diberi terapi musik selain pengobatan Ang II, mengurangi emosi \\
& & konvensional: orang-orang dengan negatif, dan meningkatkan \\
& & &
\end{tabular}


musik yang dipersonalisasi sesuai dengan emosi diri yang dilaporkan dari pasien. Terutama terdiri dari musik rakyat dan simfoni oleh Beethoven, Schubert, dan Tchaikovsky, serta lagu favorit lamban dan disengaja pasien. Perawatan dimulai dua jam setelah sarapan dan dua jam setelah makan malam dan berlangsung 30 sampai 60 menit setiap hari untuk setiap pasien, dan volumenya antara 50 sampai 60 desibel. Selain itu, masingmasing pasien mengeluarkan MP3 player kecil dengan earpiece dan musiknya tersimpan di MP3 player sehingga pasien bisa mendengarkan setiap saat. Semua pasien menerima perawatan terus menerus selama empat minggu

\begin{tabular}{lll}
\hline 2.(Gupta \& & 50 responden & Grup A tidak mendengarkan musik \\
Gupta, 2018) & dengan usia & dan Grup B setiap hari mendengarkan \\
(2016) & kehamilan & musik klasik selama sebulan dengan \\
& $28-32$ & durasi 30 menit dirumah dengan \\
minggu, yang & posisi berbaring (relaksasi). Yang \\
dibagi & pemeriksaan dilakukan 2 kali 6 jam \\
& kelompok A & sebelumdilakukan terapi dan 6 jam \\
& 25 responden & setelah dilakukan terapi. Pemeriksaan \\
tidak & sistemik dan obstetrik dilakukan \\
diperdengark & pada semua subjek. Doppler warna \\
& an musik dan & dilakukan untuk menilai aliran darah \\
kelompok B & di arteri umbilikalis bilateral dengan \\
& 25 responden & mengukur berbagai indeks doppler \\
mendengrka & secara ultrasonologis: Indeks \\
n musik & Pulsatilitas (PI), Indeks Tahanan (RI) \& \\
klasik & Rasio diastolik Sistolik (S / D ratio. \\
& Aliran darah janin secara \\
& ultrasonologis dievaluasi kembali \\
& dengan metode color doppler setelah
\end{tabular}

\begin{tabular}{lll}
\hline 3.(Nurwahy & 35 wanita & 35 responden diperdengarkan musik \\
udi, & hamil yang & klasik Mozart dengan menggunakan \\
Hermawan, & mengalami & ear phone selama 30 menit dan \\
Sajidin, \& hipertensi & kemudian diukur tekanan darah \\
Zainal) & $\begin{array}{l}\text { dengan usia } \\
\text { kehamilan }\end{array}$ & $\begin{array}{l}\text { dengan } \\
\text { (2018) }\end{array}$ \\
kehymamometer.
\end{tabular}

13-28

minggu pada

bulan Maret

2018 di

rumah sakit

Bangil dan

sampel

berjumlah 35 $\begin{array}{lr}\text { Pada kedua } & \begin{array}{l}\text { kelompok, } \\ \text { penurunan }\end{array}\end{array}$ pembuluh darah ditemukan Grup A menunjukkan peningkatan resistensi pada usia kehamilan dibandingkan dengan Grup B tidak terjadi penuruan penurunan tekanan darah. Indeks pulsatilitas di antara ketiga indeks doppler arteri umbilikalis ditemukan sebagai indikator yang paling sensitif terhadap insufisiensi foetoplacental. Dengan demikian kami menyimpulkan bahwa musik klasik memiliki efek terapeutik dalam Kehamilan diinduksi hipertensi dalam meningkatkan sirkulasi foetomaternal

Sebagian besar tekanan darah sebelum mendengarkan musik klasik Mozart PIH diklasifikasikan oleh jumlah 10 orang (53\%) dan tekanan darah sebagian besar responden setelah mendengarkan musik klasik Mozart menjadi hipertensi ringan dengan

jumlah 14 orang (74 \%). Sedangkan responden yang tidak mendengarkan musik klasik Mozart baik sebelum dan sesudah PIH digolongkan dengan jumlah 12 orang (63\%) karena tidak terdegradasi.

\begin{tabular}{llll}
\hline $\begin{array}{l}\text { 4.(Gogate \& } \\
\text { Patil, 2019) }\end{array}$ & $\begin{array}{l}40 \text { responden } \\
\text { dengan } \\
\text { hipertensi }\end{array}$ & $\begin{array}{l}\text { group B 20 diberikan terapi musik } \\
\text { dan fisioterapi dan Group A }\end{array}$ & $\begin{array}{l}\text { Untuk tekanan darah sistolik, } \\
\text { diastolik dan denyut nadi } \\
\text { menunjukkan }\end{array}$
\end{tabular}




\begin{tabular}{|c|c|c|c|}
\hline (2019) & $\begin{array}{l}\text { kehamilan } \\
\text { pada } \\
\text { trimester 3, } \\
\text { dibagi group } \\
\text { A 20 dan } \\
\text { Group B 20, } \\
\text { dengan } \\
\text { pengamblan } \\
\text { sampel } \\
\text { secara acak. }\end{array}$ & responden dengan terapi musik & $\begin{array}{l}\text { signifikan dalam pasca } \\
\text { intervensi untuk kelompok B } \\
\text { (p <0,0001). Dibandingkan } \\
\text { dengan group A, jadi } \\
\text { kombinasi terapi musik dan } \\
\text { fisioterapi aman dan efektif } \\
\text { untukmmengurangi tekanan } \\
\text { darah sistolik, tekanan darah } \\
\text { diastolik dan denyut nadi } \\
\text { dengan komplikasi yang } \\
\text { ringan. }\end{array}$ \\
\hline
\end{tabular}

Dari hasil review jurnal diatas didapatkan sampel pada penelitian ibu hamil yang mengalami hipertensi yaitu usia kehamilan 20 minggu sampai 32 minggu. Dari hasil penelitian didapatkan ada hubungan antara hipertensi dalam kehamilan dengan gawat janin, solusio plasenta, kelahiran prematur, bedah caesar, dan perdarahan postpartum.(Nahar, Nahar, Hossain, Yasmin, \& Annur, 2015; Veerbeek et al., 2015) hipertensi juga menyebakan emosi yang negatif dan hal ini akan berakibat pada kecemasan dan depresi yang meningkat, selain itu juga akan berakibat pada penurunan kulaitas hidup yaitu somatisasi, depresi, kecemasan, perilaku bermusuhan, obsesif kompulsif, ketakutan, sensitivitas antar pribadi, dan gejala kecemasan signifikan lebih terjadi pada wanita hamil dengan hipertensi dari pada wanita hamil yang sehat.(Stern C, 2014) selain berkaitan dengan penurunan kualitas hidup pada ibu hamil yang. hipertensi, jika tidak ditangani merupakan penyumbang angka kematian ibu dan bayi, Sehingga penanganan untuk hipertensi yang dilakukan di semua negara yaitu dengan cara konvensional. obat anti hipertensi yang banyak digunakan di pusat pelayanan kesehatan yaitu nifedipin sekitar 50\% pada 62 kasus hipertensi.(Chambali, Meylina, \& Rusli, 2019) dan obat anti hipertensi mempunyai efek samping yaitu mual atau muntah, sakit kepala, diare atau konstipasi, gugup, berat badan naik atau turun, jika hal ini dialami oleh ibu hamil akan berakibat sangat tidak baik baik untuk ibu maupun janinnya, sehingga diperlukan terapi pendamping selain terapi konvensional yaitu terapi musik, yang mengungkapkan bahwa terapi musik memiliki pengaruh besar pada keberhasilan perawatan konvensional untuk ibu hamil hipertensi baik tekanan darah sistolik dan diastolik. Dan pada hasil review jurnal diatas rata - rata durasinya sekitar 30 menit dan untuk volumenya disesuaikan dengan kemauan responden sehingga responden bebas memilih atau menentukan volume sendiri, hal ini juga

akan mempengaruhi keberhasilan terapi musik karena tidak ada tekanan pada dalam menjalankan terapi.

\section{Kesimpulan}

Dari telaah jurnal didapatkan terapi music memberikan manfaat yang signifikan baik dalam meningkatkan kualiatas tidur dengan konseling music pada ibu hamil dan menurunkan tekanan darah (hipertensi) pada ibu hamil dan terapi music ini dapat menenangkan mental ibu hamil yang tingkat stressnya lebih tinggi dari keadaan tidak hamil, jadi terapi music ini dapat dijadikan alternatif untuk pengobatan terapeutik pada semua klien yang membutuhkan terapi.

\section{Daftar Pustaka}

Ayuk, P. T., \& Matijevic, R. (2006). Placental ischaemia is a consequence rather than a cause of pre-eclampsia. Medical hypotheses, 67(4), 792-795.

Cao, S., Sun, J., Wang, Y., Zhao, Y., Sheng, Y., \& Xu, A. (2016). Music therapy improves pregnancyinduced hypertension treatment efficacy. Int J Clin Exp Med, 9(5), 8833-8838.

Chambali, M. A., Meylina, L., \& Rusli, R. (2019). Analisis Efektivitas Biaya Penggunaan Obat Antihipertensi pada Pasien Preeklampsia di RSUD Abdul Wahab Sjahranie Periode 2018. Paper presented at the Proceeding of Mulawarman Pharmaceuticals Conferences. 
Deveer, R., Engin-Ustun, Y., Akbaba, E., Halisdemir, B., Cakar, E., Danisman, N., . . . Candemir, Z. (2013). Association between preeclampsia and inherited thrombophilias. Fetal and pediatric pathology, 32(3), 213-217.

Geretsegger, M., Holck, U., Carpente, J. A., Elefant, C., Kim, J., \& Gold, C. (2015). Common characteristics of improvisational approaches in music therapy for children with autism spectrum disorder: Developing treatment guidelines. Journal of music therapy, 52(2), 258-281.

Gogate, M. D., \& Patil, N. R. (2019). Effects of Musical Therapy and Physiotherapy in Pregnancy Induced Hypertension. Indian Journal of Public Health Research \& Development, 10(8), 339-343.

Gupta, S., \& Gupta, V. (2018). Effect of Classical Music on Foetoplacental Circulation in Pregnancy Induced Hypertension Using Color Doppler Indices. International Journal of Physiology, 6(3), 148-151.

Kintiraki, E., Papakatsika, S., Kotronis, G., Goulis, D. G., \& Kotsis, V. (2015). Pregnancy-induced hypertension. Hormones, 14(2), 211-223.

Liao, H., Jiang, G., \& Wang, X. (2015). Music therapy as a nonpharmacological treatment for epilepsy. Expert review of neurotherapeutics, 15(9), 993-1003.

Nahar, L., Nahar, K., Hossain, M., Yasmin, H., \& Annur, B. (2015). Placental changes in pregnancy induced hypertension and its impacts on fetal outcome. Mymensingh medical journal: MMJ, 24(1), 9-17.

Nurwahyudi, D., Hermawan, Y., Sajidin, M., \& Zainal, C. Classical Music Mozart Effect of Lowering Blood Pressure First 3 months Pregnant Women Hospital Regional Genral
Bangil. President Pathumthani University, 443.

Pennings, J. L., Kuc, S., Rodenburg, W., Koster, M. P., Schielen, P. C., \& de Vries, A. (2011). Integrative data mining to identify novel candidate serum biomarkers for pre-eclampsia screening. Prenatal diagnosis, 31(12), 1153-1159.

Stern C, T. E., Mautner E, Deutsch M, Lang U, Cervar-Zivkovic M. . ( 2014). The impact of ser-vere preeclampsia on maternal quality of life. Qual Life Res, 23:, 10191026.

Veerbeek, J. H., Hermes, W., Breimer, A. Y., Van Rijn, B. B., Koenen, S. V., Mol, B. W., . . . Koster, M. P. (2015). Cardiovascular disease risk factors after early-onset preeclampsia, late-onset preeclampsia, and pregnancyinduced hypertension. Hypertension, 65(3), 600-606. 